\title{
Business and the environment
}

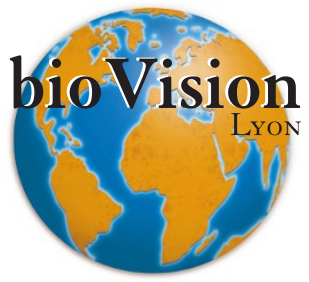

\author{
Alexander J.B. Zehnder and Harald Wulff
}

"Green investing isn't just for greens anymore. Now an increasing number of investment professionals view ecological efficiency as a vital criterion for judging the quality of a company." So said the Wall Street Journal Europe on August 14, 1996. In a similar vein, the International Herald Tribune stated on June 23, 1997, "It is in everyone's interestwhether government, business leader or consumer-to promote a healthy environment." And just recently (January 25, 1999), the Financial Times declared that "Investing in companies that care about the environment is a way to outperform the market."

What a change in perceptions of ecology and the environment, and what a long way the world has come since Rachel Carson's Silent Spring put environmental degradation squarely before the public gaze. Until the end of the 1980s a clear dividing line ran through ecological politics. At one end of the spectrum were environmentalists who demanded pollution be eliminated and ecosystems protected, whatever the cost. In their view, big business was raping the environment for the sake of profit and bares the blame for all environmental damage. At the other end, the business lobby seemed to believe that any legislation aimed at protecting the environment would hamper economic growth. In their view, protecting the environment wasted corporate financial resources that could otherwise have been used to support economic growth.

Farsighted representatives of both camps began to cross the line and thereby started to erase it. Throughout the 1990s, both sides discovered that sound business practice and a sound ecological approach are not mutually exclusive. By harnessing the mechanism of free market, pollution can be minimized, environmental protection maximized, and economic growth realized. The ecological or sustainable approaches have by no means proved to be a shackle on the economy. On the contrary, it has become increasingly clear that ecological thinking toward sustainabili-

Alexander J.B. Zehnder is at the Swiss Federal Institute for Environmental Science and Technology (EAWAG), CH-8600 Duebendorf, Switzerland (zehnder:eawag.ch). Harald Wulff is at Henkel KgaA, D-40191 Duesseldorf, Germany.

ty can act as a catalyst for innovation, development, and economic expansion.

The shift from the strict notion of protecting our environment (in essence, at all costs) to managing our resources generated a freedom of thought that allowed a change and a coalescence of views. Instrumental to this change was the report "Our Common Future" from the World Commission on Environment and Development, an indepen-

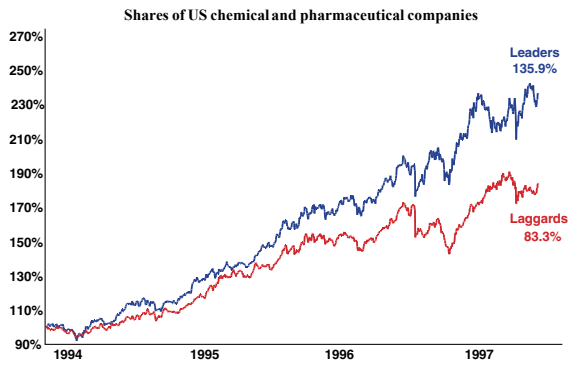

Figure 1. Sustaining competitive advantage. Shares in the US chemical and pharmaceutical companies that rated highest for a set of sustainability criteria outperformed the industry average and far outperformed the worst-rated companies. Data from SAM (sustainable asset management).

dent body set up by the United Nations and chaired by Gro Harlem Brundtland. In it, for the first time, the principles of sustainability were formulated for a larger public, and these principles not only encompassed environmental protection but went far beyond it. The publicity around the Rio Conference on Biodiversity in 1992 was a powerful dissemination tool for the philosophy of sustainability, a healthy environment and biodiversity.

Following the Rio conference, company leaders were urged by Stephan Schmidheiny and Frederico J.L. Zorraquin in their book Financing Change: The Financial Community, Eco-efficiency, and Sustainable Development:

\begin{abstract}
. to build a sustainable development reflex into corporate activities, so that when the market comes to reward eco-efficiency more systematically, company leaders will have their strategies in place, the teams trained and fit, and their stakeholders loyal.
\end{abstract}

John Elkington of the consultancy firm SustainAbility calls this strategy the triple bottom line approach: profitable operations, sound ecology and social progress. The per- formance of the stocks of sustainably managed companies-over $60 \%$ better than the worst companies-seem to support this view (Fig. 1). While adopting environmental and ecological best practice may not be a cause of outstanding business performance, it certainly appears to be an indicator of it.

The tightening link between ecology and economy is promising and creates a space and platform for alternative thinking and acting. Such a platform will not protect the human society from alarming new discoveries, such as synthetic chemicals acting as endocrine disrupters, ozone depletion, or melting of the Arctic and Antarctic ice shields because of global warming. Al Gore writes in his foreword to the book, Our Stolen Future (from Colborn, Dumanoski, \& Myers), "We can never construct a society that is completely free of risk." Nevertheless, environmental sciences and technologies can help to reduce such risks. Environmental sciences today go far beyond pollution control and ecotoxicology. Although short-term solutions will still be needed in the years ahead, consideration for the environment and the call for sustainability requires technical and societal innovations and the readiness to think in alternative ways.

Production technologies can be optimized for less pollution and diminished resource use. However, there are limits to the optimization of our daily lives' activities, our needs, wishes, and desires. The fuel economy of a car can be increased (although there is little incentive to do so in countries where gasoline costs are around $€ 0.2$ (US $\$ 0.2$ ) per liter), but how can the human desire for (excessive) mobility be changed?

The challenge for scientists and engineers is to come up with alternatives satisfying the basic necessities of human existence and development. The challenge is heightened as rapid demographic development overtakes and renders obsolete much of the progress already achieved. Creating products, technologies, and processes that meet the triple bottom line approach and encourage fair trade will benefit both North and South. Science provides the knowledge, technology, and tools for a prosperous future. To have the most impact, scientists and engineers must act within a transnational or even global political, economic, and cultural framework. 